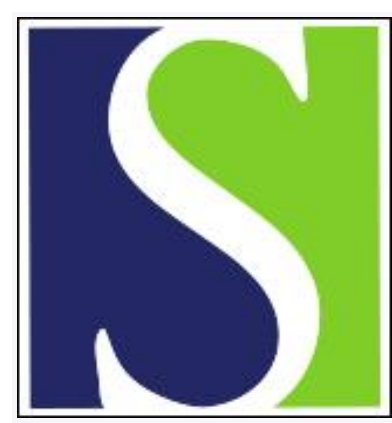

Scand J Work Environ Health 1993;19(4):255-263

https://doi.org/10.5271/sjweh.1476

Issue date: 01 Aug 1993

Monitoring occupational exposure to styrene from hemoglobin adducts and metabolites in blood.

by Christakopoulos A, Bergmark E, Zorcec V, Norppa H, Maki-Paakkanen J, Osterman-Golkar S

Affiliation: Department of Radiobiology, Arrhenius Laboratories for Natural Sciences, Stockholm University, Sweden.

This article in PubMed: www.ncbi.nlm.nih.gov/pubmed/8235514

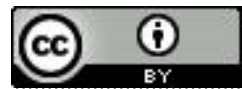




\title{
Monitoring occupational exposure to styrene from hemoglobin adducts and metabolites in blood
}

\author{
by Alex Christakopoulos, PhD, ${ }^{1,2}$ Emma Bergmark, $\mathrm{PhD},{ }^{2}$ Vlado Zorcec, ${ }^{2}$ \\ Hannu Norppa, PhD, ${ }^{3}$ Jorma Mäki-Paakkanen, PhD, ${ }^{3,4}$ Siv Osterman-Golkar, PhD ${ }^{2}$
}

\begin{abstract}
CHRISTAKOPOULOS A, BERGMARK E, ZORCEC V, NORPPA H, MÄKI-PAAKKANEN J, OSTERMAN-GOLKAR S. Monitoring occupational exposure to styrene from hemoglobin adducts and metabolites in blood. Scand J Work Environ Health 1993;19:255-63. Monitoring occupational exposure to styrene was achieved through quantification of adducts of styrene 7,8-oxide to $\mathrm{N}$-terminal valine in hemoglobin $(\mathrm{Hb})$ on the basis of the enrichment of adducted globin chains by ion-exchange chromatography and gas chromatographic-mass spectrometric analysis by the use of the $N$-alkyl Edman method. Application to blood samples from reinforced plastics workers exposed to styrene and from referents showed $\mathrm{Hb}$ adduct levels correlating with the blood styrene glycol and urinary mandelic acid concentrations. The blood styrene glycol and styrene 7,8-oxide levels of the exposed workers averaged $2.5 \mu \mathrm{mol} \cdot \mathrm{l}^{-1}$ (17 subjects) and $0.09 \mu \mathrm{mol} \cdot \mathrm{l}^{-1}$ (7 subjects), respectively. The blood styrene glycol and urinary mandelic acid content (mean $9.5 \mathrm{mmol} \cdot 1^{-1}, 17$ subjects) suggested a styrene concentration of about $300 \mathrm{mg} \cdot \mathrm{m}^{-3}(75 \mathrm{ppm})$ in the workplace air. The Hb adduct levels were low (mean $\left.28 \mathrm{pmol} \cdot \mathrm{g}^{-1}\right)$, indicating rapid detoxification of styrene 7,8-oxide in humans.
\end{abstract}

Key terms: gas chromatography-mass spectrometry, $N$-alkyl Edman procedure, styrene glycol in blood, styrene 7,8-oxide in blood, urinary mandelic acid.

Styrene is used in the production of various plastics, synthetic rubber, and polyester resins. The most extensive human exposure to styrene occurs in the reinforced plastics industry. The occupational exposure limit is at present $25 \mathrm{ppm}$ in Sweden and $20 \mathrm{ppm}$ in Finland.

The metabolism of styrene has been extensively studied in experimental animals $(1,2)$. The fate of styrene in humans with respect to uptake and disposition is also well understood (3-5). The first step in the major metabolic pathway is the formation of styrene 7,8-oxide (styrene oxide), which is hydrated to styrene glycol or conjugated with glutathione in enzyme-catalyzed reactions. The major urinary excretion products, mandelic acid, phenylglyoxylic acid and hippuric acid, are related to styrene glycol, indicating the intermediate formation of styrene oxide. Styrene oxide has been detected in the blood of animals experimentally exposed to styrene (2). Low levels of this epoxide have also been indicated in human volunteers exposed to styrene and in occupationally exposed workers (3).

1 Present address: Reserca AB, S-118 84 Stockholm, Sweden.

2 Department of Radiobiology, Arrhenius Laboratories for Natural Sciences, Stockholm University, Stockholm, Sweden.

3 Department of Industrial Hygiene and Toxicology, Institute of Occupational Health, Helsinki, Finland.

4 Present address: Division of Environmental Health, National Public Health Institute, Kuopio, Finland.

Reprint requests to: Dr S Osterman-Golkar, Department of Radiobiology, Arrhenius Laboratories for Natural Sciences, Stockholm University, S-106 91, Stockholm, Sweden.
Hemoglobin $(\mathrm{Hb})$ is suitable as a monitor of genotoxic agents because of its ready availability and its relatively long life span, which permits cumulative doses to be determined (6). The measurement of $\mathrm{Hb}$ adducts has been used for monitoring environmental factors such as occupational exposures to ethylene oxide (7-11), propylene oxide $(9,12)$, and various components of tobacco smoke $(13,14)$. In the case of ethylene oxide the sensitivity of the analysis of adducts to $\mathrm{N}$-terminal valine in $\mathrm{Hb}$ by the $N$ alkyl Edman procedure $(8,15,16)$ has been shown to be high enough to monitor exposures down to levels that may be acceptable with respect to the ensuing cancer risk (15).

In a previous study (17) using the $N$-alkyl Edman procedure to monitor $\mathrm{Hb}$ adducts in styrene-exposed workers, deuterated 2-hydroxyethylvaline was used as the internal standard. Due to the uncertainty with respect to the relative yields of the free amino acid versus the modified $\mathrm{N}$-terminal valine residue in $\mathrm{Hb}$ in the Edman reaction, the results were expressed as proportional values. The exposures of the workers ranged from 0.6 to $44 \mathrm{ppm}$. There was a large, though not significant, difference in the levels of $\mathrm{Hb}$ adducts of styrene oxide among the exposed workers and referents, primarily as a consequence of a single heavily exposed individual with an extremely high level of adducts.

In order to make $\mathrm{Hb}$ adducts useful for risk estimation, quantitative data on adduct levels are required. We have developed a procedure to determine $\mathrm{Hb}$ adducts of styrene oxide quantitatively in workers occupationally exposed to styrene. $\left({ }^{2} \mathrm{H}_{8}\right)$ Styrene 
oxide was synthesized and used for the preparation of an alkylated globin, which served as the internal standard. Adducted $\mathrm{Hb}$ chains were isolated by ionexchange chromatography according to Bergmark et al (18), and adducts of styrene oxide to $N$-terminal valine were determined by the $N$-alkyl Edman method. The procedure was applied to styrene-exposed workers and referents. In the same subjects, free styrene oxide and styrene glycol in blood and mandelic acid in urine were monitored. These metabolites give a short-term measure of styrene uptake, whereas the adducts to $N$-terminal valine in $\mathrm{Hb}$, which according to animal experiments are chemically stable (19), give a measure of the dose (defined as the time integral of the concentration of the alkylating agent) accumulated during the four months preceding the blood sampling.

The results presented in this paper are a part of a comprehensive project including measurements and comparisons of various chemical and biological end points for the biomonitoring of styrene exposure (20, 21).

\section{Materials and methods}

\section{Chemicals}

The $\left[7-{ }^{3} \mathrm{H}\right]$ styrene 7,8 -oxide $\left(3.88 \mathrm{GBq} \cdot \mathrm{mmol}^{-1}\right.$, radiochemical purity $96.5 \%$ ) was obtained from Amersham, Buckinghamshire, United Kingdom; $\left({ }^{2} \mathrm{H}_{8}\right)$ styrene $\left(98\right.$ atom- $\left.\%{ }^{2} \mathrm{H}\right)$ from Sigma, St Louis, Missouri, United States; unlabeled styrene 7,8-oxide (97\%) from Aldrich, Milwaukee, Wisconsin, United States; and styrene glycol from Merck/Schuchardt, Darmstadt, Germany. Allylbenzene glycol, synthesized according to Duverger-van Bogaert et al (22), was a gift from Dr A Löf (National Institute of Occupational Health, Solna, Sweden). Pentafluorophenyl isothiocyanate (PFPITC) (purum) and pentafluorobenzoyl chloride (puriss) were obtained from Fluka AG, Buchs, Switzerland. Formamide (analytical grade; Merck, Darmstadt, Germany) was extracted with npentane before use. The other reagents and solvents were of analytical grade and used without further purification. The $\mathrm{C}_{18}$-Sep-Pak cartridges were from Waters Associates, Milford, Massachusetts, United States; and the CM-Sepharose CL-6B was from Pharmacia, Uppsala, Sweden.

Synthesis of $\left({ }^{2} \mathrm{H}_{8}\right)$ styrene 7,8-oxide. Deuterium-substituted styrene 7,8-oxide was prepared according to a modification of the procedure described by Kologrivova et al (23). $\left({ }^{2} \mathrm{H}_{8}\right)$ Styrene $(0.5 \mathrm{~g})$ was dissolved in $2.5 \mathrm{ml}$ of ethanol in a $25-\mathrm{ml}$ round-bottomed reaction vessel. Sodium tungstate, $75 \mathrm{mg}$, was added, and the reaction mixture was heated under vigorous stirring at $60-65^{\circ} \mathrm{C}$ (oil bath) for $30 \mathrm{~min}$. The $\mathrm{pH}$ of the reaction mixture was then adjusted to 7.5 with $0.1 \mathrm{M}$ sodium hydroxide $(\mathrm{NaOH})$ in ethanol, and
$2 \mathrm{ml}$ of $30 \%$ hydrogen peroxide was added through a dropping funnel during $40 \mathrm{~min}$. The reaction mixture was kept at $65^{\circ} \mathrm{C}$ under stirring for $12 \mathrm{~h}$. Three milliliters of water $(\mathrm{pH} 7.5)$ was added, and the reaction mixture was shaken twice with $5 \mathrm{ml}$ of methylene chloride. The organic fractions were pooled and dried with anhydrous sodium sulfate and evaporated. The residue was purified on a column $(80 \times$ $0.6 \mathrm{~cm}$ ) packed with silica gel 60 and eluted with toluene:ethyl acetate (8:2). The yield was $130 \mathrm{mg}$ of material, of which $30 \mathrm{mg}$ was dissolved in $15 \mathrm{ml}$ of hexane and washed three times with $2 \mathrm{ml}$ of $0.5 \mathrm{M}$ Tris- $\mathrm{HCl}$ [tris(hydroxymethyl)aminoethanehydrochloride acid] buffer, $\mathrm{pH}$ 7.5. The $\left({ }^{2} \mathrm{H}_{8}\right)$ styrene oxide was then extracted from the hexane into $5 \mathrm{ml}$ of acetonitrile, and this procedure was repeated twice. The solvent was evaporated. The purity and identity of the compound was assessed by thin-layer chromatography, high pressure liquid chromatography, quantification of the epoxide through reaction with nicotinamide according to an improved version of the method described by Nelis \& Sinsheimer (24), and mass spectrometry. The mass spectrometric analysis was performed by use of a gas chromatograph (HP 5890), a mass-selective detector (HP5970), and a microprocessor workstation (HP 59970C).

Preparation of alkylated globins. Internal standard globin and reference globin were prepared as follows: $\left({ }^{2} \mathrm{H}_{8}\right)$ styrene oxide or unsubstituted styrene oxide $(6 \mathrm{mg})$ were mixed with ${ }^{3} \mathrm{H}$-labeled styrene oxide $(1.7 \mu \mathrm{Ci})$ and added to hemolysates from 10$\mathrm{ml}$ samples of human whole blood. The mixtures were incubated for $2 \mathrm{~h}$ at $37^{\circ} \mathrm{C}$ and then left at room temperature overnight. Globin was isolated according to Mowrer et al (25). The level of adducts to $\mathrm{N}$ terminal valine was determined on the basis of radioactivity extractable after derivatization with PFPITC. (Compare with the following text; in this case the extraction with hexane was omitted.) A parallel globin sample, treated in the same way but without the addition of PFPITC, was used as a control. The internal standard globin was also used in a study of $\mathrm{Hb}$ adduct levels in mice and rats exposed to styrene or styrene oxide (19).

Human samples. Venous blood and urine samples were collected at the end of a workshift (Thursday and Friday) from workers exposed to styrene (17 subjects) in a plant manufacturing containers from unsaturated polyester resins. The exposed workers were laminators with a mean age of 33 years and 6.7 years of average exposure to styrene. Eleven of the workers were smokers. Office workers (originally 16 subjects outside the plant and one subject from the plant) were chosen as referents. A part of each blood sample was immediately extracted for the analysis of styrene oxide. (See the following text.) 


\section{Analysis of hemaglobin adducts}

Enrichment of adducted globin chains. The blood samples were collected in heparinized tubes and were immediately put into an icebath to prevent in vitro formation of styrene 7,8-oxide. Globin was isolated from red blood cells according to Mowrer et al (25). Alpha and beta globin chains containing hydroxyphenethylvaline [here used as a collective name for diastereomers of $\beta$-hydroxyphenethyl- and, possibly, $\alpha$-(hydroxymethyl)benzyl-valine] were enriched by ion-exchange chromatography using samples of 500 $\mathrm{mg}$ of globin as described by Bergmark et al (18). The material eluting immediately before the unmodified $\beta$ and $\alpha$ chains was collected, dialyzed against distilled water, lyophilized (18), and derivatized as described in the following text for the quantification of $\mathrm{Hb}$ adducts by gas chromatography-mass spectrometry (GC-MS).

Derivatization of globin samples. The preparation and derivatization of the globin samples were performed essentially as described by Törnqvist et al (16). The conditions for the derivatization were optimized on the basis of exploratory experiments using different concentrations of reagent (PFPITC) and different incubation times. The following standard procedure was chosen for the analysis: samples of about $20-30 \mathrm{mg}$ of material were dissolved in formamide $(0.75 \mathrm{ml})$ and the internal standard globin $(50 \mu \mathrm{g})$ was added. Pyridine $(6 \mu \mathrm{l})$ and PFPITC $(6$ $\mu \mathrm{l})$ were added, and the samples were incubated at $45^{\circ} \mathrm{C}$ for $2 \mathrm{~h}$ with occasional stirring. In the original method of Törnqvist et al (16) freshly prepared $1 \mathrm{M} \mathrm{NaOH}$ was used to neutralize the globin samples. The use of pyridine for this purpose was considered handier. It was shown that neutralization with pyridine or $\mathrm{NaOH}$ gave equivalent results in the analysis of hydroxyphenethyl adducts. The samples were extracted three times with 1.5 volumes of diethyl ether, and the extracts were evaporated to dryness under nitrogen, redissolved in $2 \mathrm{ml}$ of toluene, and washed twice with water, $0.1 \mathrm{M}$ disodium carbonate, and again with water. Finally, the toluene was carefully evaporated, and the samples were dissolved in $1 \mathrm{ml}$ of methanol:water $(60: 40)$ and extracted with $2 \times 2 \mathrm{ml}$ of hexane. Hexane was evaporated under nitrogen, and the samples were dissolved in $50 \mu \mathrm{l}$ of toluene for analysis by GC-MS.

Calibration. Standard curves for pentafluorophenylthiohydantoins (PFPTH) of hydroxyphenethylvaline (see also reference 19) were prepared through the addition of various amounts of globin alkylated with unlabeled styrene oxide (reference globin) to a constant amount $(50 \mu \mathrm{g})$ of globin alkylated with $\left({ }^{2} \mathrm{H}_{8}\right)$ styrene oxide (internal standard) to $25 \mathrm{mg}$ of reference globin as a biological matrix. The mixtures were worked up according to the method already described.
Gas chromatography-mass spectrometry. PFPTH derivatives were analyzed by the use of a Finnigan 4500 gas chromatograph-mass spectrometer. The gas chromatograph was equipped with an on-column injector (OCI-3; SGE Scientific Pty Ldt, Melbourne, Australia) and a DB-5 fused silica capillary column ( $30 \mathrm{~m}, 0.32 \mathrm{~mm}$ inner diameter, $1 \mu \mathrm{m}$ phase thickness; J\&W Scientific Inc, California, United States) coupled to a deactivated precolumn $(1 \mathrm{~m}, 0.3 \mathrm{~mm}$ inner diameter) with a glass-lined stainless-steel union (SGE). (See reference 15.) The oven of the gas chromatograph was kept at $100^{\circ} \mathrm{C}$ for $1 \mathrm{~min}$; the temperature was then programmed $15^{\circ} \mathrm{C} / \mathrm{min}$ to $200^{\circ} \mathrm{C}$ and kept at this temperature for $1 \mathrm{~min}$, then programmed $10^{\circ} \mathrm{C} / \mathrm{min}$ to $300^{\circ} \mathrm{C}$ and kept at this temperature for $3 \mathrm{~min}$. The mass spectrometer was operated in the negative ion chemical ionization mode, with an ion source temperature of $100^{\circ} \mathrm{C}$, and an ionization energy of $100 \mathrm{eV}$. The ion source pressure was 0.45 torr $(60 \mathrm{~Pa})$, and the helium carrier gas pressure was 9 psi $(60 \mathrm{kPa})$. The mass spectrometer was focused at $\mathrm{m} / \mathrm{z} 424$ and 432 , the base peaks (M-HF)for the PFPTH derivatives of the valine-styrene oxide products and their deuterated variants, respectively. Quantification was based on peak areas relative to the internal standard. To correct for a possible shift in the ratio of recorded fragments, one of the samples from the calibration curve was reanalyzed on each analytical occasion.

Selection of samples. The determination of adducts to $\mathrm{N}$-terminal valine in $\mathrm{Hb}$ involved a time-consuming preisolation of adducted globin chains, and the analysis was therefore limited to samples from three referents and seven exposed workers. The exposed workers were selected on the basis of data on urinary mandelic acid concentrations in order to cover the whole range of exposures.

\section{Analysis of mandelic acid}

Mandelic acid in urine was measured according to Engström \& Rantanen (26).

\section{Analysis of styrene oxide and styrene glycol}

Styrene oxide and styrene glycol in blood were analyzed essentially as described by Wigaeus et al (3).

Blood samples of $2 \mathrm{ml}$ from four referents and seven exposed subjects were extracted for the analysis of styrene oxide. Allylbenzeneglycol, $5.67 \mathrm{ng}$, was used as the internal standard. With the analytical procedure used (3), contribution from certain conjugates of styrene glycol, such as the 2-acetate (27) - which can be extracted into hexane, and also, although certainly less susceptible than the epoxide, is hydrolyzable in acid solution - cannot at present be excluded. Therefore, the reported styrene oxide concentrations have to be considered as upper estimates of the true concentrations. Only 11 of the 34 
samples were considered suitable for gas chromatographic analysis because of contaminating material of an unknown nature in the samples.

Free styrene glycol was measured in $0.2-\mathrm{ml}$ blood samples from all of the exposed workers and eight of the referents. For these analyses $22.7 \mathrm{ng}$ of the internal standard, allylbenzeneglycol, was added.

An essentially quantitative recovery of styrene oxide through extraction with hexane was ensured through experiments in which the blood was spiked with radiolabeled styrene 7,8-oxide. Extractions of blood spiked with styrene glycol showed that no detectable amounts of the glycol $(<0.1 \%)$ were extracted with hexane (3). Calibration curves were obtained with mixtures of allylbenzene glycol $(22.7 \mathrm{ng})$ with styrene glycol (2-100 ng), the samples being processed as already described.

A Packard model 436 gas chromatograph equipped with an electron-capture detector and a fused silica capillary column (Oribond SE-54, $25 \mathrm{~m}, 0.25 \mathrm{~mm}$ inner diameter, $0.20 \mu \mathrm{m}$ phase thickness, Nordion Instruments Oy Ltd, Espoo, Finland) was used for the gas chromatography. The operating conditions were as follows: temperature programming $10^{\circ} \mathrm{C} / \mathrm{min}$ from $150^{\circ} \mathrm{C}$ to $280^{\circ} \mathrm{C}$; injector temperature $170^{\circ} \mathrm{C}$ and detector temperature $320^{\circ} \mathrm{C}$; carrier gas nitrogen.

\section{Results}

\section{Characterization of $\left({ }^{2} \mathrm{H}_{8}\right)$ styrene oxide}

The chemical structure of the $\left({ }^{2} \mathrm{H}_{8}\right)$ styrene oxide was confirmed by mass spectrometry. Mass spectra of the commercially available (unsubstituted) and synthetic $\left({ }^{2} \mathrm{H}_{8}\right)$ styrene oxides are shown in figures $1 \mathrm{la}$ and lb. The spectrum of the unsubstituted styrene oxide (figure 1a) agrees well with that published by Bido- li et al (28). The corresponding fragmentation pattern of $\left({ }^{2} \mathrm{H}_{8}\right)$ styrene oxide (figure $\left.1 \mathrm{~b}\right)$ shows an intense molecular peak at $\mathrm{m} / \mathrm{z} 128$. Loss of two mass units $\left(\mathrm{M}-{ }^{2} \mathrm{H}\right)$ resulted in a peak at $\mathrm{m} / \mathrm{z} 126$. Further fragmentation and loss of 18, 30 and 46 mass units resulted in peaks at $\mathrm{m} / \mathrm{z} 110,98$ and 82 , which corresponded to $\mathrm{M}-\mathrm{C}^{2} \mathrm{H}_{3}, \mathrm{M}-\mathrm{C}^{2} \mathrm{HO}$ and $\mathrm{M}-$ $\left(\mathrm{C}^{2} \mathrm{H}-\mathrm{C}^{2} \mathrm{H}_{2}\right) \mathrm{O}$, respectively.

Thin-layer chromatography, high-pressure liquid chromatography, and measurements of alkylating activity according to Nelis \& Sinsheimer (24) showed that the purity of the synthetic $\left({ }^{2} \mathrm{H}_{8}\right)$ styrene oxide corresponded to that of the commercially available unsubstituted compound.

\section{Characterization and quantification of PFPTH derivatives of hydroxyphenethylvaline}

Gas chromatographic analysis of the PFPTH derivatives obtained after derivatization of globin alkylated with styrene oxide showed two peaks. An identical pattern was seen with the deuterated analogues. The mass spectra obtained from each of these two peaks were almost identical. Figure 2 shows the spectra of the first peak. The molecular ions of hydroxyphenethylvaline-PFPTH and the corresponding deuterium-substituted derivatives are $\mathrm{m} / \mathrm{z}=444$ and $\mathrm{m} / \mathrm{z}=452$, respectively. The dominating fragments are $\mathrm{m} / \mathrm{z}=424$ (or 432 ) and $\mathrm{m} / \mathrm{z}=318$ (or 320 ). The former fragments were formed by loss of HF from the molecular ions, and the latter by additional loss of $\mathrm{C}_{6} \mathrm{H}_{5} \mathrm{CHO}$ (or $\mathrm{C}_{6}{ }^{2} \mathrm{H}_{5} \mathrm{C}^{2} \mathrm{HO}$ ). This type of fragmentation has been observed for adducts with a $\beta$-hydroxy group, such as 2-hydroxyethyl, 2-hydroxypropyl, and 2-hydroxy-3-butenyl $(29,30)$, suggesting that the initial attack of valine- $\mathrm{NH}_{2}$ occurred at carbon- 8 of styrene oxide. However, previous studies
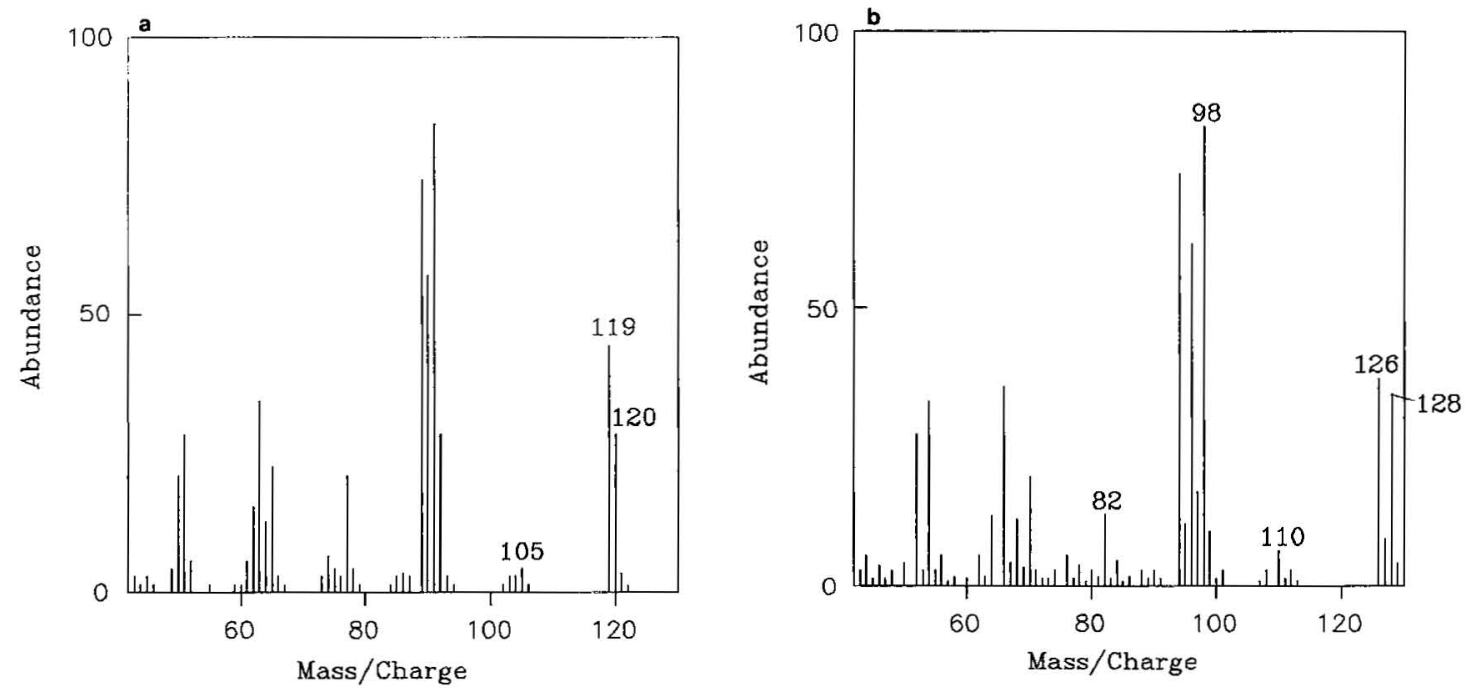

Figure 1. Mass spectra (electron impact) of commercially available styrene oxide (a) and synthetic deuterium-substituted styrene oxide (b). 
of styrene oxide [eg, in reactions with glutathione (31) and guanosine (32)] showed that both carbons of the oxirane ring are reactive. (See also reference 33.) This possibility was not studied further in the present investigation.

The fragments 341 and 349 correspond to a loss of $\left(\mathrm{CH}_{3}\right)_{2} \mathrm{CHCH}, \mathrm{CO}$, and $\mathrm{F}$ from the molecular ions. The fragments 424 and 432 were monitored for the quantification of adduct levels in globin samples.

The concentrations of adducts to $N$-terminal valine in the reference globin and the standard globin were both determined to be $1.2 \mathrm{nmol} \cdot \mathrm{mg}^{-1}$ on the basis of radioactivity extractable after derivatization with PFPITC and the specific activity prepared from the normal and deuterium-substituted styrene oxide, respectively. The standard curve showed good linearity in the range studied $(12.5-150 \mu \mathrm{g}$ of reference globin, $\mathrm{N}=6$, correlation coefficient $=0.99845$ ).

\section{Analysis of human samples}

The results of the monitoring of $\mathrm{Hb}$ adduct levels, styrene oxide, and styrene glycol in blood and mandelic acid in the urine of the exposed subjects and referents are presented in table 1 .

Hemaglobin adducts. Figure 3 shows the mass fragmentograms of adducts to $N$-terminal valine in globin from one individual worker exposed to high air concentrations of styrene. The levels of hydroxyphenethylvaline in the globin samples are given as an average for the $\alpha$ and $\beta$ chains on the assumption that the proportions of adducts to the two chains were the same in the samples and in the internal standard globin. The $\mathrm{Hb}$ adduct levels in the referents were $<13 \mathrm{pmol} \cdot \mathrm{g}^{-1}$, and the average $\mathrm{Hb}$ adduct level in the seven exposed workers was 28 (range 15-52) $\mathrm{pmol} \cdot \mathrm{g}^{-1}$.

Styrene oxide. The styrene oxide concentration in the four referents was $0.02 \mu \mathrm{mol} \cdot 1^{-1}$ or below. The values recorded for the seven exposed workers, 0.04 $0.13 \mu \mathrm{mol} \cdot \mathrm{I}^{1}$, agree with the preliminary data of Wigaeus et al (3) on styrene oxide levels in styreneexposed volunteers.

Styrene glycol. The styrene glycol concentrations in the reference samples were generally below $0.6 \mu \mathrm{mol} \cdot 1^{-1}$. (One value of $0.7 \mu \mathrm{mol} \cdot 1^{-1}$ was recorded.) The average concentration of the 17 exposed workers, 2.5 (range $0.6-6.3$ ) $\mu \mathrm{mol} \cdot \mathrm{l}^{1}$, suggested styrene exposure levels averaging about $300 \mathrm{mg} \cdot \mathrm{m}^{-3}$ in the work environment $(3,4)$.

Mandelic acid. The concentration of mandelic acid in urine was measured in the exposed workers and in the referent from the plant (19). The average concentration in the exposed subjects, $9.5 \mathrm{mmol} \cdot \mathrm{l}^{-1}$, suggested an average exposure level of about $300 \mathrm{mg} \cdot \mathrm{m}^{-3}$ (34). This finding is in agreement with the exposure estimate based on the styrene glycol concentrations.

\section{Regression analysis}

The correlation between the parameters studied was analyzed by a linear regression. (See table 2.) The analysis showed a correlation between styrene glycol in blood and mandelic acid in urine. There was also a strong correlation between the $\mathrm{Hb}$ adduct levels and these exposure parameters.
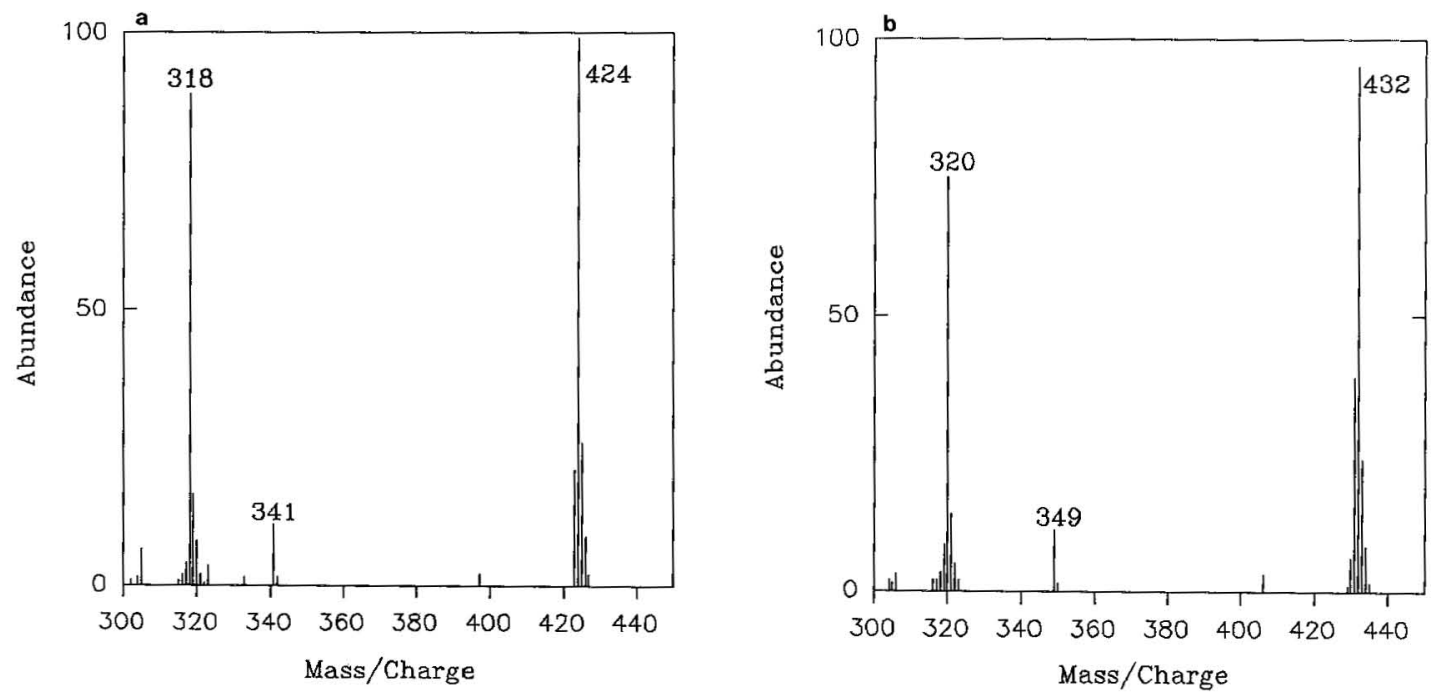

Figure 2. Mass spectra (negative ion chemical ionization) of one of the diastereomers of the pentafluorophenylthiohydantoins of hydroxyphenethylvaline (a) and the corresponding deuterated analogue (b). 
Table 1. Mandelic acid in urine, styrene oxide and styrene glycol in blood, and adducts to N-terminal valine in hemoglobin from workers exposed to styrene and from referents. (ND = not determined)

\begin{tabular}{|c|c|c|c|c|c|c|}
\hline $\begin{array}{l}\text { Subject } \\
\text { number }\end{array}$ & $\underset{\text { (years) }}{\text { Age }}$ & $\begin{array}{l}\text { Years of } \\
\text { styrene } \\
\text { exposure }\end{array}$ & $\begin{array}{c}\text { Mandelic } \\
\text { acid } \\
\left(\mathrm{mmol}^{-1} \mathbf{1}^{-1}\right)\end{array}$ & $\begin{array}{c}\text { Styrene } \\
\text { oxide }^{\mathrm{a}} \\
(\mu \mathrm{mol} \cdot \mid-1)\end{array}$ & $\begin{array}{c}\text { Styrene } \\
\text { glycol } \\
(\mu \mathrm{mol} \cdot \mid-1)\end{array}$ & $\begin{array}{l}\text { Hemoglobin } \\
\text { adducts } \\
\left(\text { pmol } \cdot g^{-1}\right)\end{array}$ \\
\hline \multicolumn{7}{|c|}{ Referents } \\
\hline $\begin{array}{c}1 \\
2^{\mathrm{b}} \\
3^{\mathrm{b}} \\
4 \\
5 \\
6 \\
7^{\mathrm{b}} \\
8^{\mathrm{b}} \\
9 \\
10 \\
11\end{array}$ & $\begin{array}{l}25 \\
39 \\
35 \\
39^{c} \\
24 \\
29 \\
38 \\
33^{c} \\
26 \\
29 \\
42\end{array}$ & $\begin{array}{l}\bar{z} \\
\bar{z} \\
\bar{z} \\
\bar{z} \\
\bar{z} \\
\overline{-}\end{array}$ & $\begin{array}{c}N D \\
N D \\
N D \\
N D \\
N D \\
N D \\
N D \\
N D \\
N D \\
<1 \\
N D \\
N D\end{array}$ & $\begin{array}{c}\text { ND } \\
\text { ND } \\
<0.02 \\
\text { ND } \\
\text { ND } \\
\text { ND } \\
<0.02 \\
\text { ND } \\
0.02 \\
0.02 \\
\text { ND }\end{array}$ & $\begin{array}{r}<0.6 \\
<0.6 \\
<0.6 \\
<0.6 \\
<0.6 \\
<0.6 \\
<0.6 \\
0.7 \\
\text { ND } \\
\text { ND } \\
\text { ND }\end{array}$ & $\begin{array}{l}\text { ND } \\
\text { ND } \\
\text { ND } \\
\text { ND } \\
\text { ND } \\
\text { ND } \\
\text { ND } \\
\text { ND } \\
\leq 13 \\
\leq 10 \\
\leq 8\end{array}$ \\
\hline Means & 33 & - & $<1$ & $\leq 0.02$ & $<0.6$ & $\leq 13$ \\
\hline \multicolumn{7}{|c|}{$\begin{array}{l}\text { Styrene-exposed } \\
\text { workers }\end{array}$} \\
\hline $\begin{array}{l}12^{\mathrm{b}} \\
13^{\mathrm{b}} \\
14 \\
15^{\mathrm{b}} \\
16 \\
17^{\mathrm{b}} \\
18^{\mathrm{b}} \\
19 \\
20 \\
21 \\
22 \\
23 \\
24 \\
25 \\
26 \\
27 \\
28^{\mathrm{b}}\end{array}$ & $\begin{array}{l}28 \\
32 \\
23 \\
40 \\
37 \\
38 \\
33^{c} \\
21 \\
32 \\
31 \\
50^{\circ} \\
39^{c} \\
29 \\
28 \\
26 \\
38 \\
36\end{array}$ & $\begin{array}{c}3 \\
7 \\
7 \\
11 \\
14 \\
14 \\
0.2 \\
3 \\
5 \\
3 \\
12 \\
5 \\
3 \\
3 \\
0.5 \\
15 \\
8\end{array}$ & $\begin{array}{r}16.6 \\
2.7 \\
6.9 \\
2.9 \\
9.1 \\
7.3 \\
9.6 \\
19.5 \\
<1 \\
8.7 \\
21.5 \\
9.5 \\
14.4 \\
9.1 \\
6.3 \\
16.5 \\
<1\end{array}$ & $\begin{array}{l}0.08 \\
0.04 \\
0.12 \\
0.04 \\
\text { ND } \\
\text { ND } \\
\text { ND } \\
\text { ND } \\
\text { ND } \\
\text { ND } \\
\text { ND } \\
0.12 \\
\text { ND } \\
0.11 \\
\text { ND } \\
0.13 \\
\text { ND }\end{array}$ & $\begin{array}{l}4.0 \\
1.0 \\
1.6 \\
1.1 \\
2.6 \\
1.2 \\
2.7 \\
6.3 \\
0.6 \\
1.6 \\
4.5 \\
3.2 \\
1.9 \\
4.0 \\
2.2 \\
3.2 \\
0.9\end{array}$ & $\begin{array}{l}35 \\
\text { ND } \\
23 \\
15 \\
\text { ND } \\
\text { ND } \\
23 \\
52 \\
19 \\
\text { ND } \\
\text { ND } \\
\text { ND } \\
31 \\
\text { ND } \\
\text { ND } \\
\text { ND } \\
\text { ND }\end{array}$ \\
\hline Means & 33 & 6.7 & 9.5 & 0.09 & 2.5 & 28 \\
\hline
\end{tabular}

a Contributions from hexane-extractable hydrolyzable conjugates of styrene glycol to the determined styrene oxide concentra tion cannot be excluded.

b Nonsmoker.

c Female.

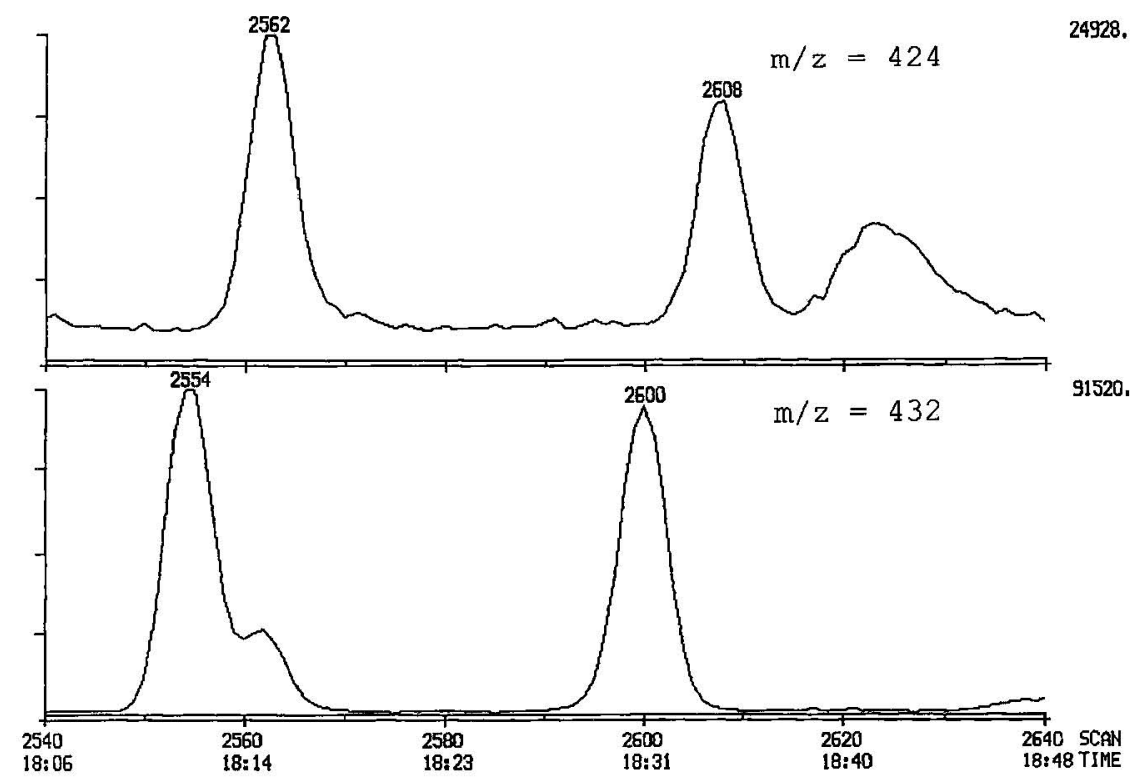

Figure 3. Mass fragmentogram (negative ions) of pentafluorophenylthiohydantoins (PFPTH) of hydroxyphenethylvaline in globin from a worker exposed at high air concentrations of styrene. Adducted globin chains were enriched on CM-Sepharose CL-6B before the derivatization. Analyte: $\mathrm{m} / \mathrm{z} 424$, scans 2562 and 2608 . Internal standard: $\mathrm{m} / \mathrm{z} 432$, scans 2554 and 2600. 
Table 2. Analysis of the interrelationships between the studied parameters by straight line regression $(y=k x+I)$. The level of hydroxyphenethylvaline in hemoglobin is given in picomoles per gram of globin, mandelic acid in millimoles per liter, and sty. rene oxide and styrene glycol in micromoles per liter.

\begin{tabular}{llrrr}
\hline$y$ & $x$ & $k$ & $l$ & $n$ \\
\hline Styrene oxidea & Styrene glycol & 0.025 & 0.021 & 0.788 \\
Styrene glycol & Mandelic acid & 0.205 & 0.554 & 17 \\
Hemoglobin adducts & Styrene glycol & 5.92 & 7.9 & 12.3 \\
Hemoglobin adducts & Mandelic acid & 1.59 & 0.937 \\
Hemoglobin adducts & Styrene oxide & 165 & 0.924 \\
\hline
\end{tabular}

a Contributions from hexane-extractable hydrolyzable conjugates of styrene glycol to the determined styrene oxide concentra. tion cannot be excluded.

\section{Discussion}

A method for analyzing hydroxyethyl and other lowmolecular weight adducts to $N$-terminal valine in $\mathrm{Hb}$ was developed by Törnqvist et al $(15,16,25)$. We employed this method with a few modifications to allow quantification of the low adduct levels in styrene-exposed workers. An additional step for purification of the PFPTH derivative, involving extraction from methanol-water $(60: 40)$ to hexane, was introduced. This extraction removed a main fraction of the impurities (including PFPTH derivatives of more hydrophilic alkylvalines, such as hydroxyethyl- and hydroxypropyl-valine-PFPTH) still remaining in the PFPTH extracts washed according to Törnqvist et al $(15,16)$. The enrichment of adducted $\alpha$ and $\beta$ globin chains on CM-Sepharose CL-6B prior to derivatization resulted in a substantial improvement in the analytical sensitivity. The gain in sensitivity, if expressed in terms of the amount of protein in the parent chain compared with the amount of protein in the enriched fraction, was approximately tenfold. To compensate for recovery in all of the steps of the analytical procedure, a globin alkylated with $\left({ }^{2} \mathrm{H}_{8}\right)$ styrene oxide was used as an internal standard.

The method was applied for the quantitative determination of $\mathrm{Hb}$ adducts in samples from workers exposed to styrene in the reinforced plastics industry and from matched referents. Free styrene glycol and styrene oxide (see footnote in table 1) in blood and mandelic acid in urine were analyzed as measures of exposure. A correlation was found between the concentrations of blood metabolites and mandelic acid. The average values $\left(2.5 \mu \mathrm{mol} \cdot 1^{-1}\right.$ for styrene glycol and $9.0 \mathrm{mmol} \cdot \mathrm{H}^{-1}$ for mandelic acid) suggested an air concentration of about $300 \mathrm{mg} \cdot \mathrm{m}^{-3}$ (about $75 \mathrm{ppm}$ ) of styrene in the work environment. $\mathrm{The} \mathrm{Hb}$ adduct levels correlated with the concentration of styrene glycol in blood and mandelic acid in urine. The average $\mathrm{Hb}$ adduct level of hydroxyphenethylvaline was $28 \mathrm{pmol} \cdot \mathrm{g}^{-1}$ for the seven exposed subjects.

The origin of the background levels of hemoglobin adducts is not known, but these levels are probably produced as methodological artifacts rather than reflecting true adduct levels. Styrene has been measured in adipose tissue of nonoccupationally exposed persons (35). The average concentration in the tis- sue was estimated to correspond to an inhaled concentration of $0.476 \mathrm{ppm}$ of styrene in the air. This finding indicates that styrene is present in unknowingly exposed humans, a situation which may give rise to a background level of styrene oxide adducts to $\mathrm{Hb}$. However, since $75 \mathrm{ppm}$ gave a $\mathrm{Hb}$ adduct level of $30 \mathrm{pmol} \cdot \mathrm{g}^{-1}$, the background level of 10 $\mathrm{pmol} \cdot \mathrm{g}^{-1}$ seems too high and may indeed reflect an artifact. This possibility will be studied further.

The weekly uptake of styrene at $300 \mathrm{mg} \cdot \mathrm{m}^{-3}$ is estimated to be $1.25 \mathrm{mmol} \cdot \mathrm{kg}^{-1}$ of body weight, on the assumption of an alveolar ventilation rate of $0.21 \cdot \mathrm{min}^{-1}(\mathrm{~kg} \text { body weight })^{-1}$ and an absorption of $90 \%$ of the compound from alveolar air. The steady state adduct level attained after prolonged exposure corresponds to nine weeks of cumulative uptake [ie, $\left.11.2 \mathrm{mmol}(\mathrm{kg} \text { body weight })^{-1}\right]$ and gives a value of $0.03 \mathrm{nmol} \cdot \mathrm{g}^{-1}$ for hydroxyphenethylvaline in $\mathrm{Hb}$ in humans. This adduct level is approximately 10 and 30 times lower than would have been obtained in rat and mouse, respectively, at a corresponding styrene uptake (19). This finding may demonstrate a relatively rapid detoxification of styrene oxide in humans.

Ethylene oxide is a known animal carcinogen (36). Studies at this laboratory (Hussain et al, unpublished) have demonstrated that styrene oxide has a somewhat (approximately twofold) higher chemical reactivity and a higher mutagenic effectiveness in Escherichia coli $\mathrm{Sd}-4$ than ethylene oxide. If compared at equal adduct levels in deoxyribonucleic acid (DNA), the two compounds would give a similar mutagenic response. Thus a tentative risk estimation for styrene could be based on tissue doses of styrene oxide and the cancer-initiating potency of ethylene oxide. Occupational exposure to ethylene oxide at $1 \mathrm{ppm}$ (the occupational concentration limit in Sweden for new establishments) gives a steady state $\mathrm{Hb}$ adduct level of about $2.4 \mathrm{nmol} \cdot \mathrm{g}^{-1}$ for hydroxyethylvaline (10). According to the present study, occupational exposure to styrene at $100 \mathrm{ppm}$ gives a value of approximately $0.04 \mathrm{nmol} \cdot \mathrm{g}^{-1}$. Thus exposure at $100 \mathrm{ppm}$ of styrene and $0.02 \mathrm{ppm}$ of ethylene oxide would give similar adduct levels.

Steady-state concentrations of epoxides during exposure can also give a measure of dose. Data on environmental and instantaneous blood concentrations of ethylene oxide in exposed workers show that 
exposure at $1 \mathrm{ppm}$ results in an average concentration of $0.13 \mu \mathrm{mol} \cdot \mathrm{l}^{-1}$ for ethylene oxide in blood (37). According to this study exposure to styrene at $100 \mathrm{ppm}$ gives about $0.09 \mu \mathrm{mol} \cdot \mathrm{l}^{-1}$ for styrene oxide (upper estimate) (footnote in table 1). Exposure at $100 \mathrm{ppm}$ of styrene or $0.7 \mathrm{ppm}$ of ethylene oxide would give the same epoxide blood concentrations. If an even distribution of styrene oxide in blood is assumed (ie, similar concentrations inside and outside the erythrocytes), $100 \mathrm{ppm}$ of styrene or $1.4 \mathrm{ppm}$ of ethylene oxide would be expected to give similar adduct levels. The discrepancy between expected and found adduct levels may be explained by a much lower concentration of styrene oxide in the erythrocytes (where it is available for reaction with $\mathrm{Hb}$ ) than in the plasma, where a main fraction of the compound could be noncovalently bound to proteins.

\section{Acknowledgments}

This work was financially supported by the Swedish Work Environment Fund and the Swedish Cancer Society. The synthesis and characterization of $\left({ }^{2} \mathrm{H}_{8}\right)$ styrene oxide and the internal standard globin was sponsored by the Ecetoc Task Force on styrene. Support has also been obtained from Shell International Research Maatschappij BV.

The authors thank $\mathrm{H}$ Kivistö, MSc, for the urine mandelic acid determinations.

\section{References}

1. Löf A, Gullstrand E, Byfält Nordqvist M. Tissue distribution of styrene, styrene glycol and more polar styrene metabolites in the mouse. Scand J Work Environ Health 1983;9:419-30.

2. Löf $A$, Gullstrand E, Lundgren E, Byfält Nordqvist M. Occurrence of styrene 7,8-oxide and styrene glycol in mouse after the administration of styrene. Scand J Work Environ Health 1984;10:179-87.

3. Wigaeus E, Löf A, Bjurström R, Byfält Nordqvist M. Exposure to styrene: uptake, distribution, metabolism and elimination in man. Scand J Work Environ Health 1983;9:479-88.

4. Wigaeus E, Löf A, Byfält Nordqvist M. Uptake, distribution, metabolism and elimination of styrene in man: a comparison between single exposure and coexposure with acetone. Br J Ind Med 1984;41:53946.

5. Ramsey JC, Andersen ME. A physiologically based description of the inhalation pharmacokinetics of styrene in rats and humans. Toxicol Appl Pharmacol 1984;73:159-75.

6. Osterman-Golkar S, Ehrenberg L, Segerbäck D, Hällström I. Evaluation of genetic risks of alkylating agents: II. haemoglobin as a dose monitor. Mutat Res 1976;14:1-10.

7. Calleman CJ, Ehrenberg L, Jansson B, OstermanGolkar S, Segerbäck D, Svensson K, et al. Monitoring and risk assessment by means of alkyl groups in hemoglobin in persons occupationally exposed to ethylene oxide. J Environ Pathol Toxicol 1978;2:42742.

8. Farmer PB, Bailey E, Gorf SM, Törnqvist M, Osterman-Golkar S. Monitoring human exposure to ethyl- ene oxide by the determination of haemoglobin adducts using gas chromatography-mass spectrometry. Carcinogenesis 1986;7:637-40.

9. Högstedt B, Bergmark E, Törnqvist M, OstermanGolkar S. Chromosomal aberrations and micronuclei in lymphocytes in relation to alkylation of hemoglobin in workers exposed to ethylene oxide and propylene oxide. Hereditas 1990;113:133-38.

10. Duus U, Osterman-Golkar S, Törnqvist M, Mowrer J, Holm S, Ehrenberg L. Studies of determinants of tissue dose and cancer risk from ethylene oxide exposure. In: Freij L, ed. Proceedings of the symposium: risk from genotoxic substances in the environment; 1988 Oct 3-5; Stockholm (Sweden). Solna (Sweden): Swedish National Chemicals Inspectorate, 1989:141 53.

11. Tates AD, Grummt T, Törnqvist $\mathrm{M}$, Farmer PB, van Dam FJ, van Mossel $\mathrm{H}$, et al. Biological and chemical monitoring of occupational exposure to ethylene oxide. Mutat Res 1991;250:483-97.

12. Osterman-Golkar S, Bailey E, Farmer PB, Gorf SM, Lamb JH. Monitoring exposure to propylene oxide through the determination of hemoglobin alkylation. Scand J Work Environ Health 1984;10:99-102.

13. Törnqvist $M$, Osterman-Golkar S, Kautiainen A Jensen S, Farmer PB, Ehrenberg L. Tissue doses of ethylene oxide in cigarette smokers determined from adduct levels in hemoglobin. Carcinogenesis 1986;7: 1519-21.

14. Bryant MS, Skipper PL, Tannenbaum SR, Maclure M. Hemoglobin adducts of 4-aminobiphenyl in smokers and nonsmokers. Cancer Res 1987;47:602-8

15. Törnqvist M, Mowrer J, Jensen S, Ehrenberg L. Monitoring of environmental cancer initiators through hemoglobin adducts by a modified Edman method. Anal Biochem 1986;154:255-66.

16. Törnqvist M, Kautiainen A, Gatz RN, Ehrenberg L. Hemoglobin adducts in animals exposed to gasoline and diesel exhausts: 1. alkenes. J Appl Toxicol 1988; $8: 159-70$.

17. Brenner DD, Jeffrey AM, Latriano L, Wazneh L, Warburton $\mathrm{D}$, Toor $\mathrm{M}$, et al. Biomarkers in styrene-exposed boat-builders. Mutat Res 1991;261:225-36.

18. Bergmark E, Belew M, Osterman-Golkar S. Separation and enrichment of alkylated globin chains as a means of improving the sensitivity of hemoglobin adduct measurements. Acta Chem Scand 1990;44: $630-5$.

19. Osterman-Golkar S, Christakopoulos A, Zorcec V, Svensson K. Dosimetry of styrene 7,8-oxide in styrene and styrene oxide-exposed mice and rats by quantitation of hemoglobin adducts. Chem Biol Interact. In press.

20. Walles SAS, Norppa H, Osterman-Golkar S, MäkiPaakkanen J. Single-strand breaks in DNA of peripheral lymphocytes of styrene-exposed workers. In: Bartsch H, Hemminki K, O'Neill IK, ed. Methods for detecting DNA damaging agents in humans: applications in cancer epidemiology and prevention. Lyon: International Agency for Research on Cancer, 1988 (IARC scientific publications; no 89)

21. Mäki-Paakkanen J, Walles S, Osterman-Golkar S, Norppa H. Single strand breaks, chromosome aberrations, sister chromatid exchanges and micronuclei in blood lymphocytes of workers exposed to styrene during the production of reinforced plastics. Environ Mol Mutag 1991;17:27-31.

22. Duverger-van Bogaert M, Noel G, Rollman B, Cumps J, Roberfroid M, Mercier M. Determination of oxide synthetase and hydratase activities by a new highly sensitive gas chromatographic method using styrene and styrene oxide as substrates. Biochem Biophys Acta 1978;526:77-84.

23. Kologrivova NE, Kheisits LA, Shumskaya EV, 
Kamaeva ZV. Preparation of styrene oxide by oxidation of styrene with hydrogen peroxide in the presence of catalyst. Maslozhirov promyslennost 1980;2:289.

24. Nelis HJCF, Sinsheimer JE. A sensitive fluorimetric procedure for the determination of aliphatic epoxides under physiological conditions. Anal Biochem 1981; 115:151-7.

25. Mowrer J, Törnqvist M, Jensen S, Ehrenberg L. Modified Edman degradation applied to hemoglobin for monitoring occupational exposure to alkylating agents. Toxicol Environ Chem 1986;11:215-31.

26. Engström K, Rantanen J. A new gas chromatographic method for determination of mandelic acid in urine. Int Arch Arbeitsmed 1974;33:163-7.

27. Battistini C, Bellucci G, Mastrorilli E. The formation of phenylethane 1,2-diol 2-acetate in the metabolism of styrene oxide by rabbit liver microsomes in vitro. Xenobiotica 1979;9:57-61.

28. Bidoli F, Airoldi L, Pantarotto C. Quantitative determination of styrene 7,8-oxide in blood by combinent gas chromatography - multiple ion detection mass fragmentography. J Chromatog 1980;196:314-8.

29. Osterman-Golkar S, Kautiainen A, Bergmark E, Håkansson K, Mäki-Paakkanen. Hemoglobin adducts and urinary mercapturic acids in rats as biological indicators of butadiene exposure. Chem Biol Interact 1991;80:291-302.

30. Törnqvist M. Monitoring and cancer risk assessment of carcinogens, particularly alkenes in urban air [dissertation]. Stockholm: Stockholm University, 1989.

31. Hernandez O, Yagen B, Cox RH, Smith BR, Foure- man GL, Bend JR, et al. Stereospecificity and regioselectivity in the reaction of epoxides with glutathione. In: McKinney JD ed. Environmental health chemistry - the chemistry of environmental agents as potential human hazards. Ann Arbor, MI: Ann Arbor Science Publishers Inc, 1980:425-44.

32. Hemminki K, Försti A, Mustonen R, Savela K. DNA adducts in experimental cancer research. J Cancer Res Clin Oncol 1986;112:181-8.

33. Ehrenberg L, Hussain S. Genetic toxicity of some important epoxides. Mutat Res 1981;86:1-113.

34. American Conference of Governmental Industrial Hygienists (ACGIH). Styrene monomer: recommended BEI. In: ACGIH, ed. Documentation of the threshold limit values and biological exposure indices. Cincinnati, OH: ACGIH, 1986: BEI29-BEI33.

35. Pierce CH, Tozer TN. Styrene in adipose tissue of nonoccupationally exposed persons. Environ Res 1992; $58: 230-5$.

36. International Agency for Research on Cancer (IARC). Allyl compounds, aldehydes, epoxides and peroxides. Lyon: IARC, 1987. (IARC monographs on the evaluation of the carcinogenic risk of chemicals to humans; no 36.)

37. Brugnone F, Perbellini L, Faccini GB, Pasini F, Bartolucci GB, DeRosa E. Ethylene oxide exposure: biological monitoring by analysis of alveolar air and blood. Int Arch Occup Environ Health 1986;58:105_12.

Received for publication: 18 February 1993 